\title{
Studi Jangkauan Layanan Taman Kota Lumintang, Denpasar, Bali
}

\author{
I Gusti Ngurah Made Dwipayana ${ }^{1}$, Naniek Kohdrata ${ }^{\star *}$, R Suyarto² \\ 1. Prodi Arsitektur Lanskap, Fakultas Pertanian, Universitas Udayana, Jl. P.B. Sudirman, Denpasar, \\ Indonesia \\ 2. Prodi Agroekoteknologi, Fakultas Pertanian, Universitas Udayana, Jl. P.B. Sudirman, Denpasar, \\ Indonesia \\ *E-mail: naniek_kohdrata@unud.ac.id
}

\begin{abstract}
Study of Service Range on Lumintang City Park, Denpasar, Bali. Lumintang City Park is one of the green open spaces in Denpasar City. People frequently visit the city park to do some outdoor activities. The objectives of this study are to determine the service distance of Lumintang Park as a city park by its users in the context of the user's home range, and to determine the frequency of user visits Lumintang City Park. The research method used in this study is a questionnaire method. Geographic Information System (GIS) is used to track down the domicile of the respondents. The study shows the area that serves most by Lumintang City Park is within the radius of $4 \mathrm{~km}$. People who live in Denpasar are the dominant user of this city park. The highest frequency of visit to Lumintang City Park is one to two times a week.
\end{abstract}

Keywords: service range, city park, urban open space.

\section{Pendahuluan}

RTH merupakan salah satu tempat yang sering dikunjungi oleh masyarakat untuk beraktivitas. Salah satu bentuk RTH yang sering digunakan untuk aktivitas masyarakat adalah taman kota. Fungsi taman kota adalah sebagai sarana kesehatan publik dan sarana rekreasi murah yang dapat diakses oleh masyarakat dari berbagai golongan. Bagi masyarakat, keberadaan RTH seperti taman kota dapat digunakan sebagai tempat berolahraga, beristirahat dan bersantai setelah menjalani kegiatan rutin. Taman kota juga dapat berperan sebagai agen pembangun komunitas, yaitu suatu tempat bagi masyarakat untuk dapat saling bersosialisasi dan berkumpul. Nilai penting keberadaan suatu taman kota dapat dilihat dari frekuensi kunjungan masyarakat ke taman tersebut. Intensitas kunjungan masyarakat ke taman kota dapat menjadi indikasi bahwa masyarakat merasa nyaman dengan lokasi tersebut dan memang memerlukan keberadaan taman kota untuk beraktivitas.

Kota Denpasar saat ini memiliki tiga taman kota, antara lain Taman Kota Lumintang, Taman Puputan Badung I Gusti Ngurah Made Agung, dan Lapangan Puputan Margarana Niti Mandala Renon. Taman Kota Lumintang merupakan taman kota yang banyak dikunjungi masyarakat karena memiliki fasilitas yang cukup lengkap, fasitilas berupa jogging track, lapangan rumput untuk bersantai dan menikmati air mancur, area olahraga kalistenik, dan taman burung. Observasi awal menunjukan frekuensi kunjungan masyarakat pengguna berada pada rentang kunjungan sesekali saja ke Taman Kota Lumintang dan hingga yang rutin berkunjung ke Taman Kota Lumintang. Aktivitas yang sering dijumpai pada pengguna Taman Kota Lumintang antara lain bersosialisasi, rekreasi, dan berolahraga. Hampir setiap hari Taman Kota Lumintang ramai dikunjungi masyarakat dengan peningkatan jumlah pengunjung terutama pada hari Sabtu dan Minggu.

Data dari observasi awal yang mengindikasikan bahwa terdapat dua kategori besar pengunjung taman, yaitu yang sesekali dan rutin menimbulkan pertanyaan mengapa hal itu terjadi, apakah terdapat faktor jarak atau aktifitas yang berperan. Menurut Haryadi dan Setiawan (2010), ruang kegiatan manusia (home range) adalah batas-batas umum pergerakan berkala penduduk, yang terdiri dari beberapa rona dan lokasi, serta jaringan penghubung antara rona. Sehingga menarik untuk diteliti bagaimana Taman Kota Lumintang berfungsi untuk melayani pengguna dari aspek jangkauan ruang berkegiatan berkala penggunanya.

Jarak jangkauan wilayah pengguna Taman Kota Lumintang dapat menjadi suatu indikator ketersediaan taman publik di lingkungan pemukiman masyarakat. Selain itu belum diketahui dari wilayah mana 
saja asal sebagian besar pengunjung Taman Kota Lumintang. Hal ini penting untuk diketahui sehingga dapat dijadikan suatu bahan pertimbangan dalam membuat suatu RTH publik yang baru.

\section{Metode}

Penelitian ini dilakukan di Taman Kota Lumintang, Dauh Puri Kaja, Denpasar Utara, Kota Denpasar, Provinsi Bali

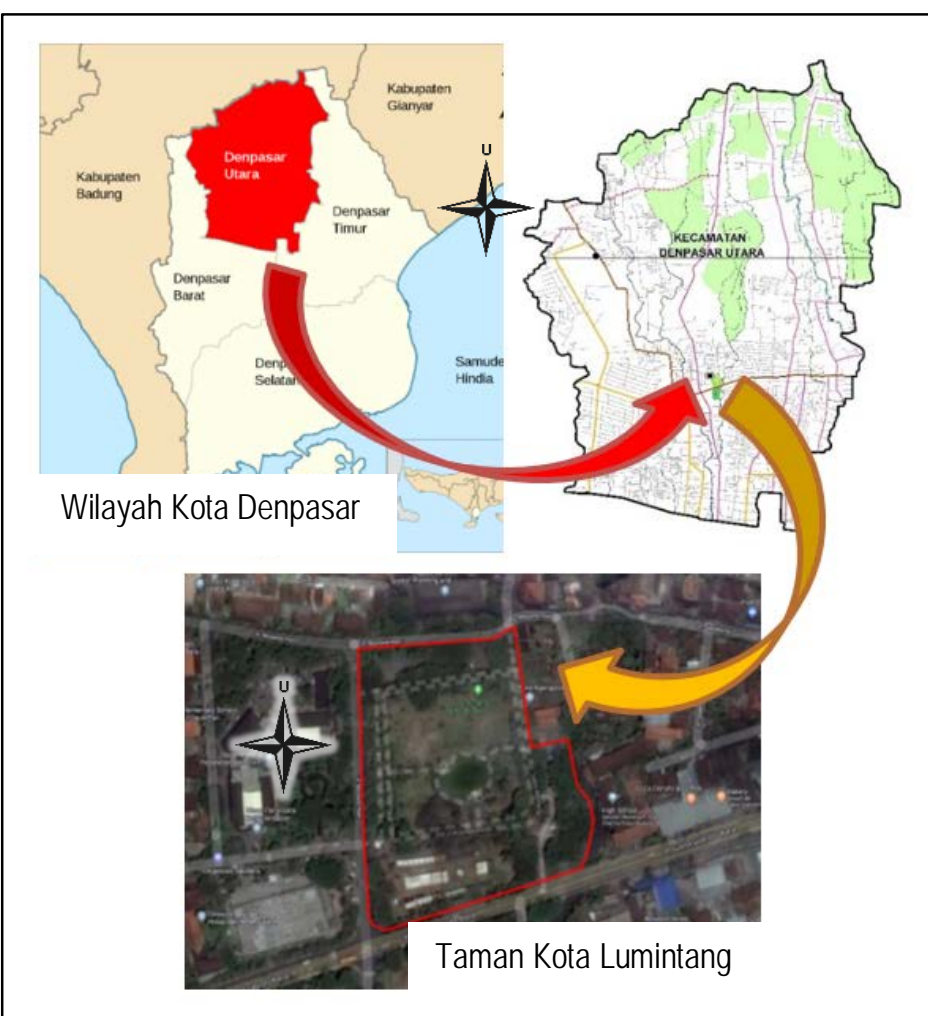

Gambar 1. Penelitian dilakukan selama dua minggu (14 hari) yakni pada bulan Oktober 2018.

Gambar 1. Lokasi Penelitian (Google Map, 2018)

Alat dan bahan yang digunakan dalam penelitian ini berupa peta Kota Denpasar, kamera, laptop, perangkat lunak (Microsoft Office Word, Microsoft Office Excel, Adobe Photoshop, Arcview GIS dan Auto CAD), dan lembar kuesioner. Penelitian dilakukan dengan menggunakan metode survey. Data yang dikumpulkan dalam penelitian ini berupa data primer yaitu data yang diperoleh dari kuesioner, serta data sekunder yaitu data yang diperoleh dari studi pustaka dapat berupa literatur, buku, dan dokumen. Sampel dari penelitian ini adalah pengguna Taman Kota Lumintang, diambil menggunakan metode accidental sampling, yaitu anggota sampel yang diambil tidak direncanakan terlebih dahulu tetapi pada siapa saja yang dijumpai pada saat pengambilan sampel. Pada penelitian ini sampel yang digunakan adalah pengguna yang sudah berumur minimal 16 tahun. Penyebaran kuesioner dilakukan setiap hari, pada pagi hari antara pukul $07.00-09.00$ WITA dan sore antara 17.00 - 19.00 WITA. Metode analisis data menggunakan teknik analisis spasial dan deksriptif. Analisis spasial dalam hal ini digunakan dalam pemetaan domisili pengunjung dengan melakukan digitasi dari data domisili pengunjung dan dipetakan, sedangkan frekuensi kunjungan rutin pengunjung dan aktivitasnya akan ditampilkan secara grafik dan dianalisa secara deskriptif. Analisa data untuk kunjungan masyarakat diklasifikasikan menurut frekuensi jumlah kunjungan pengguna tiap minggu. Frekuensi kunjungan dihitung dalam presentase menggunakan formula: 


$$
\text { Persentase }=\frac{f}{N} \times 100 \%
$$

Keterangan:

$$
\begin{aligned}
& f=\text { frekuensi } \\
& N=\text { jumlah responden }
\end{aligned}
$$

\section{Hasil dan Pembahasan}

\subsection{Kota Denpasar}

Denpasar merupakan ibu kota Provinsi Bali. Kota Denpasar berbatasan wilayah dengan Kabupaten Badung di sebelah Utara dan Barat, Kabupaten Gianyar di sebelah Timur, serta Selat Badung di sebelah Selatan. Berdasarkan data dari Badan Pusat Statistik Provinsi Bali tahun 2018, luas wilayah Kota Denpasar adalah 127,78 km². Wilayah Kota Denpasar secara administratif terdiri dari empat kecamatan dan 43 desa atau kelurahan. Kota Denpasar sebagai ibu kota di Bali tidak lepas dari permasalahan pertambahan penduduk. Meningkatnya jumlah penduduk dari tahun ke tahun akan berpengaruh terhadap meningkatnya jumlah ruang terbangun seperti pemukiman dan pertokoan. Hal ini tentu saja akan berdampak pada berkurangnya RTH kota dimana lahan hijau seperti area persawahan akan berubah fungsi menjadi lahan terbangun. Namun sebaliknya kebutuhan masyarakat perkotaan akan ketersediaan RTH semakin meningkat. Wahyudi (2009) mengatakan bahwa RTH dibutuhkan untuk mengurangi stress karena kehidupan masyarakat perkotaan yang menuntut aktivitas, mobilitas, serta persaingan yang tinggi.

\subsection{Ruang Terbuka Hijau Publik Kota Denpasar}

Menurut peraturan Daerah Kota Denpasar No. 27 tahun 2011 tentang Tata Ruang Wilayah Kota Denpasar 2011-2031, komposisi luas RTH di Kota Denpasar adalah sekitar 46,63 km² atau sekitar 36,28\% dari luas Kota Denpasar. Saat ini Kota Denpasar memiliki beberapa RTH yang dapat digunakan oleh masyarakat untuk beraktivitas, dapat berupa taman kota maupun taman huta raya. Lapangan Puputan Badung I Gusti Ngurah Made Agung, terletak di Kecamatan Denpasar Barat dengan letak yang strategis karena berada di jantung Kota Denpasar atau titik nol Kota Denpasar, luasan RTH tersebut $\pm 33.810 \mathrm{~m}^{2}$, dikelilingi pusat perkantoran, perekonomian, dan pendidikan. Lapangan Puputan Margarana Niti Mandala Denpasar, terletak di Denpasar Timur dengan luas $\pm 143.730 \mathrm{~m}^{2}$, dan terdapat sebuah monument perjuangan rakyat bali yang dikenal dengan sebutan Monumen Bajra Sandhi. Taman Kota Denpasar atau biasa disebut dengan Taman Kota Lumintang merupakan bekas pusat pemerintahan Kabupaten Badung, taman ini terletak di Jalan Gatot Subroto, Denpasar Utara dengan luas $\pm 30.000 \mathrm{~m}^{2}$. Hutan bakau, dikenal pula dengan sebutan Hutan Mangrove yaitu Taman Hutan Raya Ngurah Rai yang terletak di Denpasar Selatan. Luas hutan bakau tersebut adalah $\pm 13.730 .000 \mathrm{~m}^{2}$. Keberadaan hutan bakau saat ini sangat diperlukan sebagai pelindung dan penyeimbang ekosistem pantai. Kawasan hutan bakau yang berada di Denpasar Selatan saat ini juga telah difungsikan sebagai objek pariwisata.

\subsection{Taman Kota Lumintang}

Taman Kota Lumintang terletak di tengah Kota Denpasar dengan luas lapangan $\pm 30.000 \mathrm{~m}^{2}$. Taman Kota Lumintang dikelilingi oleh beberapa sekolah, kantor instansi, berbagai pusat perbelanjaan dan pemukiman penduduk (Gambar 2), sehingga ramai dikunjungi oleh masyarakat pada pagi maupun sore hari. Masyarakat yang datang sebagian besar berdomisili di wilayah Kota Denpasar, namun ada pula masyarakat yang berasal dari luar Kota Denpasar (Tabel 1). Data penelitian menunjukan jumlah pengguna Taman Kota Lumintang didominasi oleh penduduk Denpasar sebesar 91\%. Pengunjung terbanyak berasal dari wilayah Denpasar Utara, disusul oleh kecamatan Denpasar Barat, Denpasar Timur, dan Denpasar Selatan serta beberapa kecamatan yang berada di wilayah Kabupaten Badung dan Gianyar. 
Tabel 1. Sebaran Wilayah Domisili Pengunjung di Taman Kota Denpasar

\begin{tabular}{cclc}
\hline No. & Kabupaten/Kota & Kecamatan & Jumlah Responden (Orang) \\
\hline 1 & & Utara & 51 \\
2 & \multirow{2}{*}{ Denpasar } & Barat & 22 \\
3 & & Selatan & 6 \\
4 & & Timur & 12 \\
\hline 5 & \multirow{2}{*}{ Badung } & Abiansemal & 3 \\
6 & Kuta Utara & 2 \\
\hline 7 & Gianyar & Sukawati & 4 \\
\hline \multicolumn{7}{r}{ Total } & & 100 \\
\hline
\end{tabular}

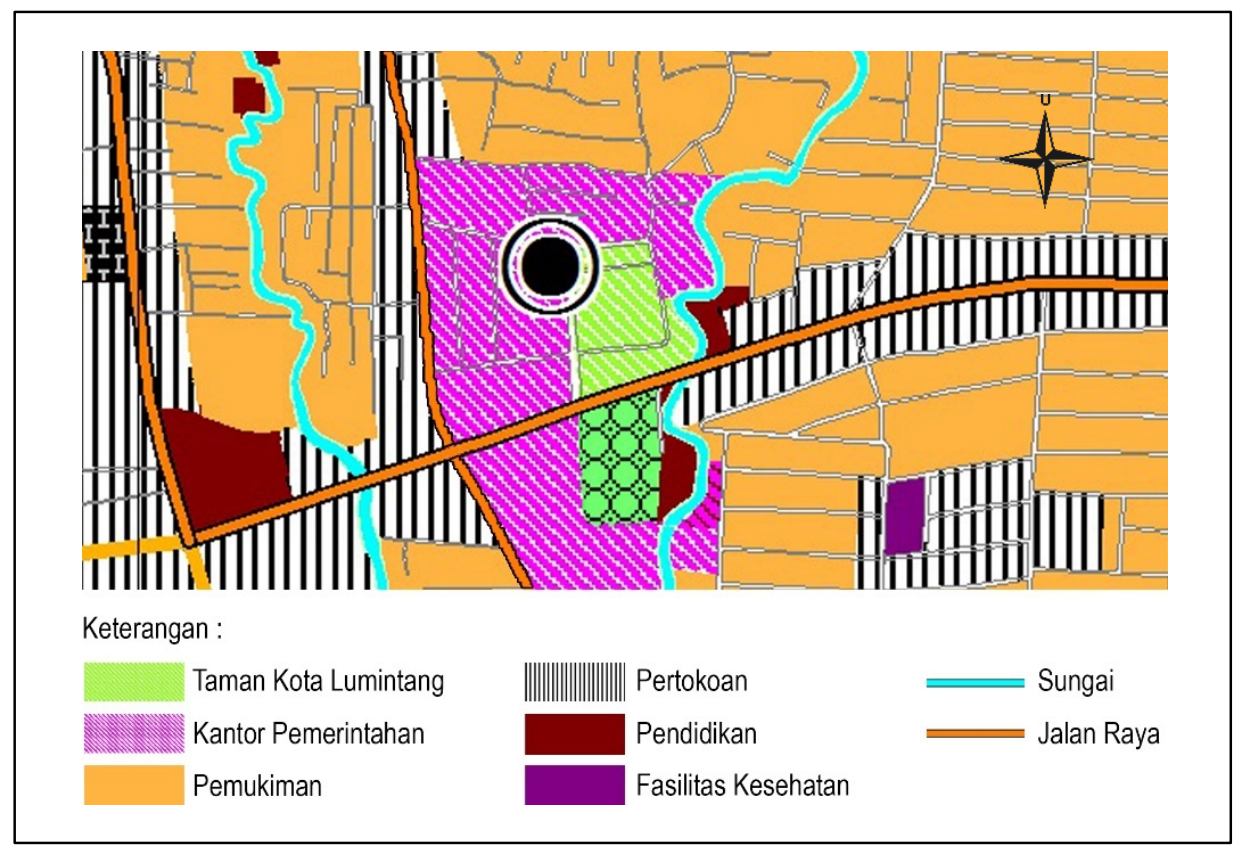

Gambar 2. Denah Pola Ruang (Peta Rencana Pola Ruang Wilayah Kota Denpasar, 2017)

\subsection{Aktivitas Terhadap Karakteristik Pengunjung}

Berdasarkan hasil kuesioner, sebagian besar pengunjung Taman Kota Lumintang bergender laki-laki yaitu 56 responden sedangkan perempuan berjumlah 44 responden. Jenis aktivitas yang dilakukan di lapanganpun berbeda-beda. Gambar 3 merupakan grafik aktivitas pengunjung berdasarkan gender. Grafik ini memberi gambaran bahwa masyarakat pengunjung Taman Kota Lumintang menggunakan taman kota ini sebagai tempat untuk melakukan aktivitas olahraga dan rekreasi.

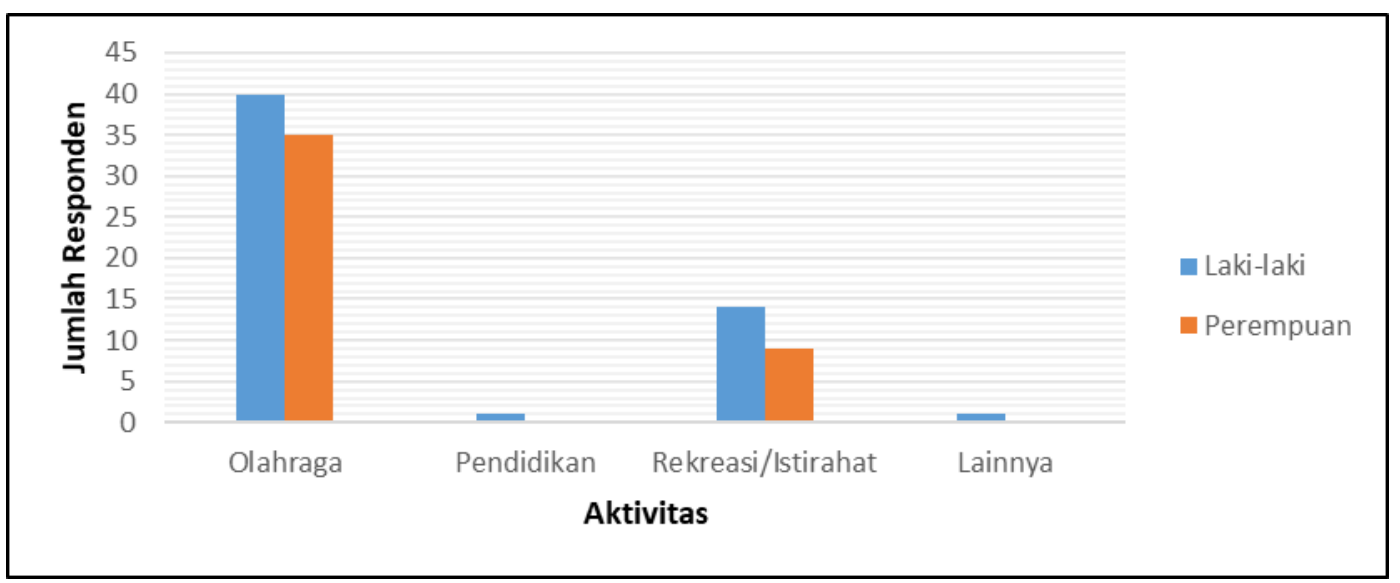

Gambar 3. Aktivitas Pengunjung Menurut Gender 
Pengguna Taman Kota Lumintang berasal dari berbagai usia, baik tua maupun muda. Pengguna Taman Kota Lumintang terbanyak berada pada usia 16-25 tahun yaitu sebanyak $40 \%$, disusul oleh responden yang berjumlah cukup banyak yaitu berusia $>45$ tahun sebanyak 24\%, kemudian usia 26-35 dan usia 36-45 masing-masing 18\%. Hal ini menunjukan bahwa keberadaan Taman Kota Lumintang dapat memenuhi kebutuhan aktivitas di luar ruangan untuk semua usia. Jenis aktivitas yang dilakukan di Taman Kota Lumintang dipengaruhi oleh faktor usia (Gambar 4).

Grafik pada Gambar 4 menunjukan bahwa aktivitas olahraga didominasi oleh pengguna yang berusia remaja (16-25 tahun) dan orang tua (>45 tahun), namun ada pula pengguna dewasa (36-45 tahun) dan dewasa muda (26-35 tahun) yang juga berolahraga di Taman Kota ini.

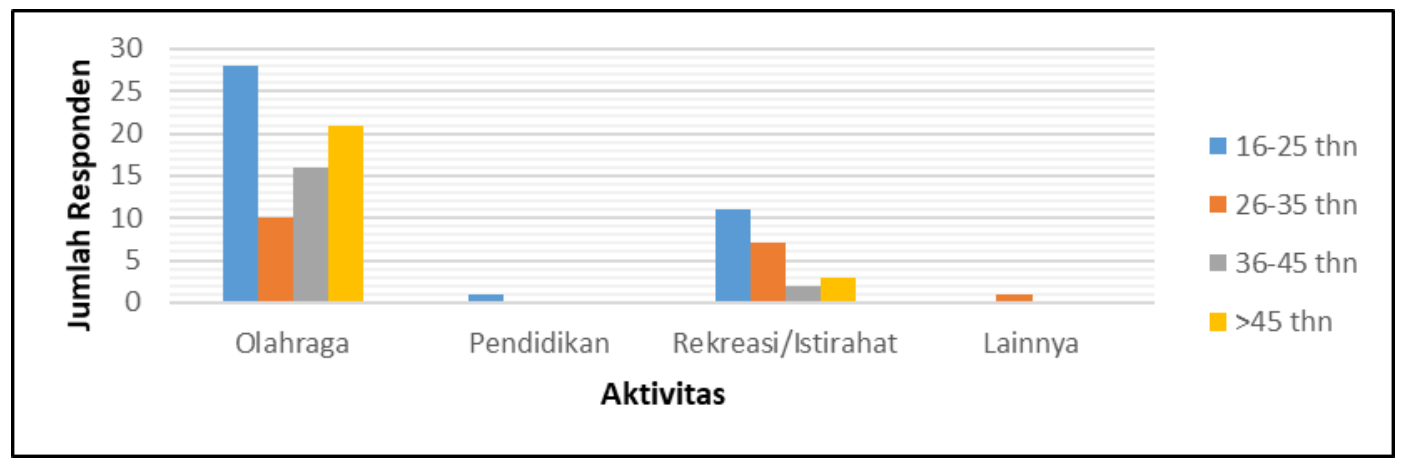

Gambar 4. Aktivitas Pengunjung Menurut Usia

Taman Kota Lumintang sebagai tempat untuk rekreasi dan istirahat didominasi oleh pengguna remaja dan dewasa muda, namun untuk pengguna yang berusia $>45$ tahun cenderung lebih sedikit dibandingkan dengan aktivitas olahraga, sehingga dari Gambar 4 memberikan suatu gambaran bahwa pengunjung yang berusia $>45$ tahun cenderung untuk melakukan aktivitas olahraga dibandingkan hanya sekedar berekreasi/beristirahat di taman kota ini. Dari keempat jenis aktivitas yang telah dijabarkan, masyarakat yang datang ke Taman Kota Lumintang sebagian besar melakukan aktivitas Olahraga.

Jenis pekerjaan dapat mempengaruhi seseorang dalam memanfaatkan waktu yang mereka miliki untuk beraktivitas di Taman Kota Lumintang. Mereka mengisi kekosongan waktu yang mereka miliki dengan datang Taman Kota Lumintang untuk berekreasi maupun berolahraga. Berikut ini merupakan grafik hubungan antara pekerjaan dan aktivitas yang dilakukan di Taman Kota ini (Gambar 5).

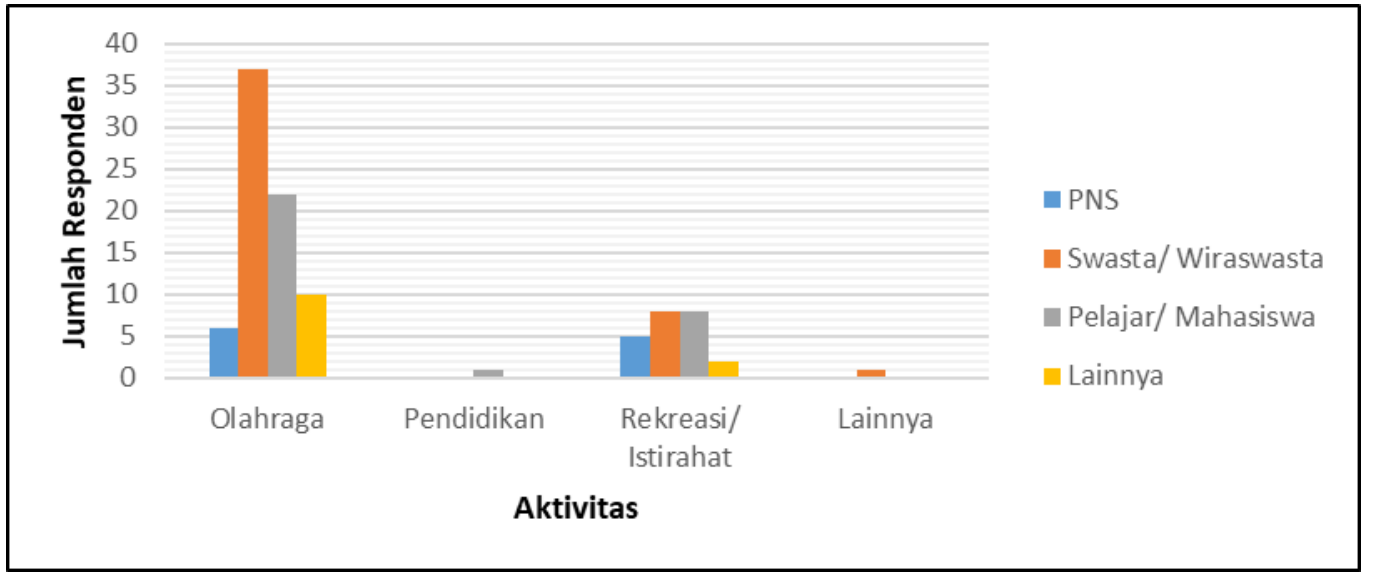

Gambar 5. Aktivitas Pengunjung Menurut Pekerjaan

Aktivitas olahraga didominasi oleh masyarakat yang bekerja pada sektor swasta/wiraswasta dan kelompok pelajar/mahasiswa. Faktor-faktor yang mungkin menjadi penyebab perbedaan ini ialah waktu luang yang tersedia. Responden yang bekerja pada sektor swasta terutama yang bekerja di bidang perhotelan dan 
restoran menggunakan sistem kerja shift, sehingga waktu luang yang mereka miliki dapat digunakan untuk berolahraga, begitu pula dengan responden yang berwiraswasta. Gambar 5 menunjukan bahwa sebagian besar pengguna dari tiga sektor pekerjaan datang ke Taman Kota Lumintang untuk berolahraga. Pada sektor pekerjaan PNS, swasta/wiraswasta, pelajar/mahasiswa, dan lainnya juga mengalokasikan waktu yang mereka miliki untuk sekedar berekreasi maupun beristirahat di Taman Kota Lumintang. Hal ini menbuktikan bahwa masyarakat kota masih memerlukan ruang terbuka hijau publik sebagai tempat mereka beraktivitas untuk melepas penat dari kegiatan sehari-hari.

\subsection{Jangkauan Wilayah Pengunjung}

Berdasarkan hasil olah data (Tabel 1), pengguna Taman Kota Lumintang sebagian besar merupakan masyarakat Kota Denpasar yaitu sebanyak 91 responden. Namun hasil kuesioner juga menunjukan bahwa Taman Kota Lumintang tidak hanya digunakan oleh masyarakat Kota Denpasar, terdapat pula masyarakat di luar Kota Denpasar yang datang ke taman kota ini. Masyarakat tersebut berasal dari Kabupaten Badung sebanyak 5 responden dan Kabupaten Gianyar sebanyak 4 responden, sehingga dapat dikatakan bahwa jangkauan wilayah pengguna Taman Kota Lumintang cukup luas, tidak hanya terbatas masyarakat di Kota Denpasar Saja (Gambar 6).

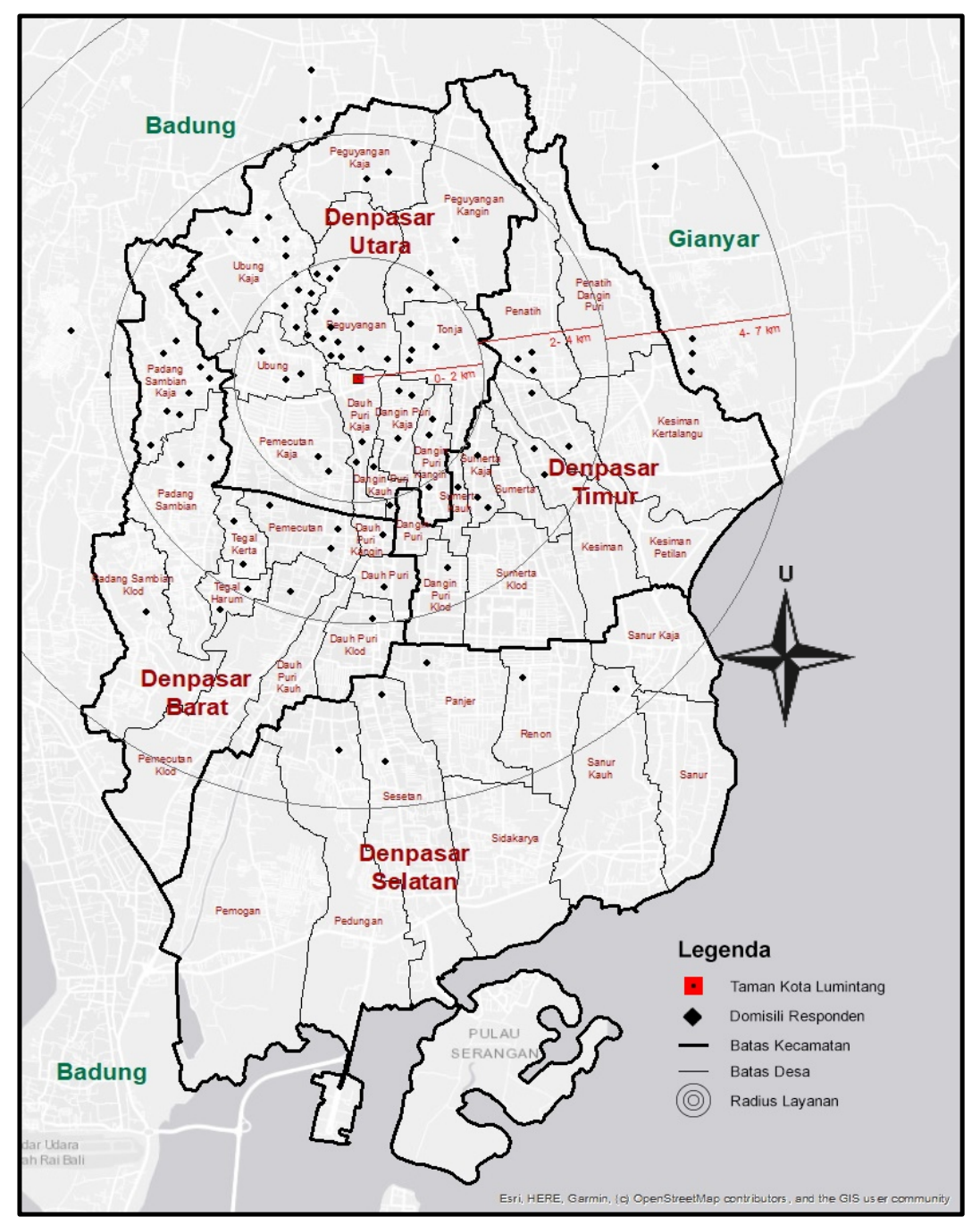

Gambar 6. Analisa Jangkauan Wilayah Pengguna Taman Kota Lumintang 
Tabel 2. Jumlah Responden Berdasarkan Radius Layanan

\begin{tabular}{cccc}
\hline No & Radius Layanan & Jumlah Responden & Persentase \\
\hline 1 & $0-2 \mathrm{~km}$ & 36 & $36 \%$ \\
2 & $2-4 \mathrm{~km}$ & 47 & $47 \%$ \\
3 & $4-7 \mathrm{~km}$ & 17 & $17 \%$ \\
\hline
\end{tabular}

Taman Kota Lumintang merupakan ruang publik yang secara administratif terletak di Kecamatan Denpasar Utara, sehingga berdasarkan tabulasi data penelitian masyarakat pengguna Taman Kota Lumintang terbanyak berasal dari wilayah Kecamatan Denpasar Utara. Masyarakat yang datang dari Kecamatan Denpasar Utara. Sebagian masyarakat (51 responden) berdomisili pada jarak $0 \mathrm{~km}-4 \mathrm{~km}$ dari Taman Kota Lumintang.

Masyarakat Kecamatan Denpasar Utara yang menggunakan Taman Kota Lumintang, terbanyak berasal dari Desa Peguyangan dan Desa Ubung Kaja. Kemudian Desa Peguyangan Kangin dan Desa Tonja dengan jumlah responden masing-masing 4 orang. Desa Dangin Puri Kaja, Desa Dangin Puri Kangin, Desa Peguyangan Kaja, dan Desa Ubung masing-masing dengan jumlah responden 3 orang. Desa Dangin Puri Kauh, Desa Dauh Puri Kaja dan Desa Pemecutan Kaja masing-masing 2 orang. Ruang terbuka hijau yang terdapat di Kecamatan Denpasar Utara berupa lahan pertanian seluas 760 hektar, yaitu sebesar 24,19\% dari total luas Denpasar Utara. Pada wilayah Desa Peguyangan Kangin dan Peguyangan Kaja, daerah ini masih memiliki ruang terbuka hijau seperti persawahan. Ketersediaan ruang terbuka hijau dapat menjadi faktor yang menyebabkan masyarakat dari desa tersebut tidak banyak yang datang ke Taman Kota Lumintang karena masih terdapat ruang bagi mereka untuk beraktivitas melepas kepenatan. Begitu juga dengan Desa Peguyangan, desa ini memiliki area persawahan yang cukup luas, namun akses jalan yang mudah dan berdekatan dengan Taman Kota Lumintang membuat pengunjung dari daerah ini tidak sedikit.

Masyarakat pengguna Taman Kota Lumintang terbanyak kedua adalah berasal dari Kecamatan Denpasar Barat yaitu sebanyak (22 responden). Menurut Badan Pusat Statistik, wilayah ini merupakan kawasan padat penduduk dengan jumlah penduduk yang tinggi, tertinggi kedua setelah Kecamatan Denpasar Selatan (Denpasar Dalam Angka 2018). Masyarakat pengguna Taman Kota Lumintang yang berasal dari Kecamatan Denpasar Barat berdomisili pada radius $2 \mathrm{~km}-6 \mathrm{~km}$. Kecamatan Denpasar Barat memiliki RTH publik yaitu Lapangan Puputan Badung. Lokasi taman terletak pada perbatasan antara Kecamatan Denpasar Barat, Denpasar Timur, dan Denpasar Utara. Letak taman yang berada di pojok timur Denpasar Barat, dan berbatasan dengan pojok barat Kecamatan Denpasar Timur mengakibatkan masyarakat dari beberapa desa di Denpasar Barat dan Denpasar Timur datang ke Lapangan Puputan Badung ini. Hal ini dapat terjadi karena masyarakat lebih mudah menjangkau lokasi Lapangan Puputan Badung dari pada menjangkau lokasi Taman Kota Lumintang.

Masyarakat di Kecamatan Denpasar Timur berada pada peringkat ketiga dari aspek jumlah kunjungan, yaitu sebanyak 12 responden. Denpasar Timur masih memiliki cukup banyak RTH, baik publik ataupun non publik. Selain Lapangan Renon, ruang terbuka publik yang terdapat di wilayah Denpasar Timur adalah GOR Ngurah Rai. Masyarakat pengguna taman yang berasal dari Kecamatan Denpasar Timur berdomisili pada radius 2-4 km dari Taman Kota Denpasar. Masyarakat yang berdomisili di wilayah Desa Penatih Dangin Puri, Desa Kesiman Kertalangu, dan Desa Kesiman Petilan tidak banyak atau bahkan tidak terdapat masyarakat yang datang ke Taman Kota Lumintang. Hal ini mungkin disebabkan karena pada di wilayah desa atau di sekitar desa tersebut masih terdapat RTH yang lebih mudah dijangkau, seperti Lapangan Renon yang memang terletak di wilayah Desa Sumerta Kelod yang relatif lebih dekat dari segi jarak tempuh masyarakat di wilayah tersebut.

Responden yang berdomisili di wilayah Kecamatan Denpasar Selatan berjumlah paling sedikit diantara ketiga kecamatan di Kota Denpasar yaitu sebanyak 6 responden. Hal ini disebabkan oleh jarak antara Denpasar Selatan dengan jarak Taman Kota Lumintang yang jauh $( \pm 6,5 \mathrm{~km})$ sehingga lebih jauh jarak yang harus ditempuh untuk menuju lokasi taman.

Dari pembahasan di atas dapat dinyatakan bahwa lokasi dari suatu taman kota menentukan jangkauan layanan dari taman itu sendiri. Walaupan data menunjukan pola fluktuasi jumlah pengguna Taman Kota 
Lumintang pada tiap kecamatan berbeda-beda, dapat dilihat dari luasnya jangkauan wilayah pengguna dari masing-masing kecamatan. Keberadaan Taman Kota Lumintang untuk wilayah Kecamatan Denpasar Utara, mayoritas digunakan oleh masyarakat yang berdomisili antara radius 0-4 km dari Taman Kota Lumintang. Di wilayah kecamatan Denpasar Barat mayoritas digunakan oleh masyarakat yang berdomisili antara radius 4-6 $\mathrm{km}$. Untuk wilayah kecamatan Denpasar Timur mayoritas digunakan oleh masyrakat yang berdomisili antara radius $2-4 \mathrm{~km}$.

\subsection{Frekuensi dan Durasi Kunjungan Pengguna}

Jumlah frekuensi kunjungan masyarakat yang datang ke Taman Kota Lumintang sangat bervariasi. Hal ini dipengaruhi oleh jenis aktivitas yang dilakukan masing-masing individu setiap hari, serta bagaimana perilaku individu dalam memanfaatkan waktu yang dimilikinya. Variasi kunjungan masyarakat berkisar antara 1-7 kali dalam seminggu. Data persentase frekuensi kunjungan masyarakat selama satu minggu ditunjukkan oleh Gambar 7.

Berdasarkan data yang didapat, terlihat bahwa frekuensi kunjungan masyarakat terbanyak adalah satu sampai dua kali seminggu. Namun ada pula masyarakat yang hampir setiap hari datang ke Taman Kota Denpasar. Berdasarkan hasil analisis data responden, masyarakat yang frekuensi kunjungannya satu atau dua kali dalam seminggu biasanya datang pada hari Sabtu dan Minggu.

Variasi lamanya waktu yang dihabiskan oleh masyarakat pengguna Taman Kota Lumintang berbeda-beda (Tabel 3).

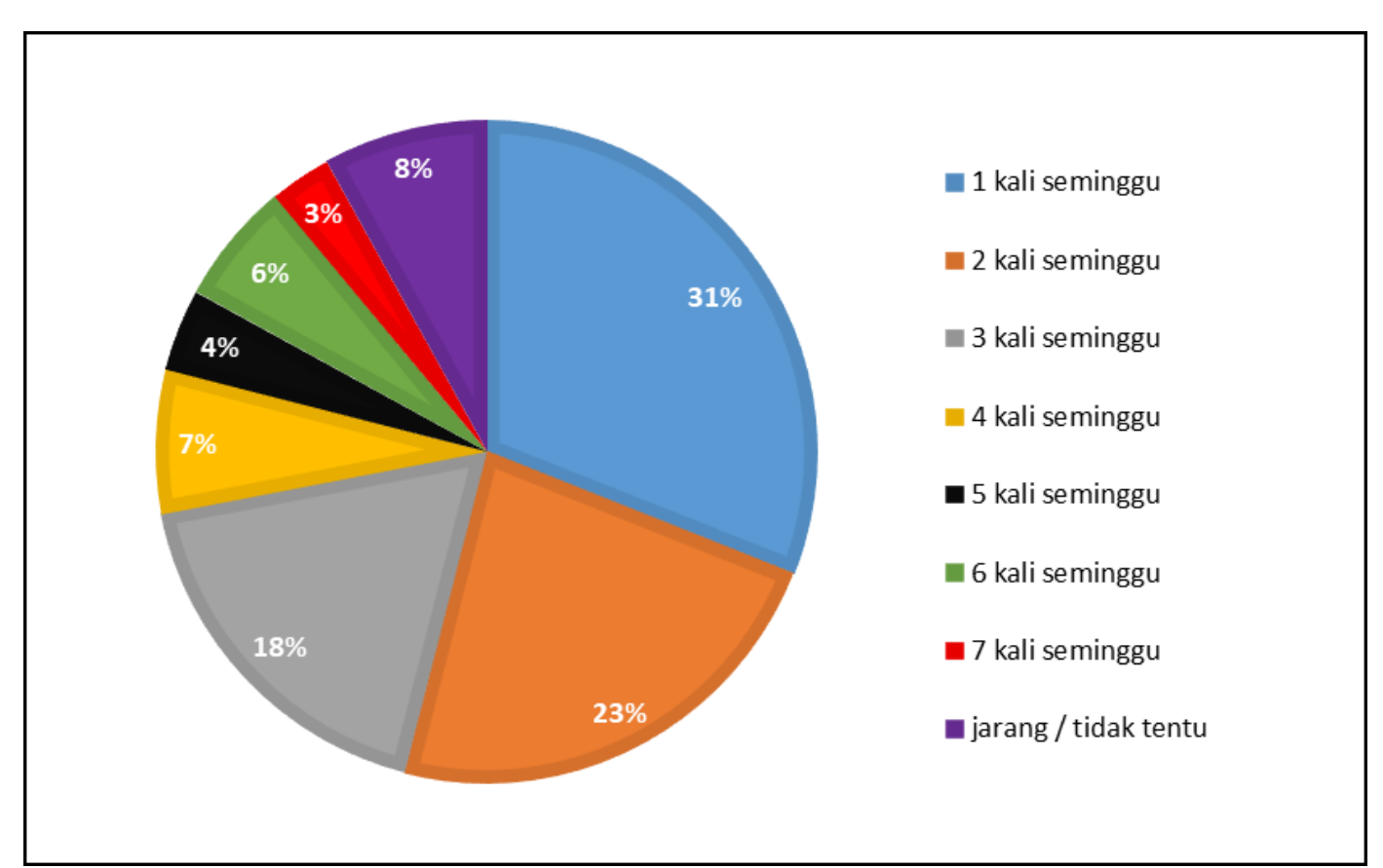

Gambar 7. Frekuensi Kunjungan Masyarakat

Tabel 3. Waktu Dihabiskan di Taman Kota Lumintang Per Kunjungan

\begin{tabular}{|c|c|c|c|c|}
\hline \multirow{2}{*}{ No } & \multirow{2}{*}{ Aktivitas } & \multicolumn{3}{|c|}{ Lama Waktu } \\
\hline & & 1-2 jam & 3-4 jam & $>5 \mathrm{jam}$ \\
\hline 1 & Olahraga & 56 & 19 & - \\
\hline 2 & Pendidikan & 1 & - & - \\
\hline 3 & Rekreasi/istirahat & 19 & 4 & - \\
\hline 4 & Lainnya & 1 & - & - \\
\hline & Total & 77 & 23 & 0 \\
\hline
\end{tabular}


Dalam satu kali kunjungan sebagian besar masyarakat pengguna Taman Kota Lumintang menghabiskan waktu selama 1-2 jam di lokasi. Mayoritas masyarakat yang menghabiskan 1-2 jam waktunya di Taman Kota Lumintang untuk aktivitas olahraga. Aktivitas lain yang menghabiskan waktu 1-2 jam adalah rekreasi, aktivitas pendidikan seperti mengerjakan tugas perkuliahan, dan lainnya seperti duduk-duduk menikmati pemandangan dan udara sekitar taman. Namun ada pula masyarakat yang menghabiskan waktunya antara 3-4 jam untuk berada di Taman Kota Lumintang dengan melakukan olahraga kalistenik dengan volume yang tinggi, sehingga membutuhkan waktu cukup lama di taman ini. Hal ini dapat menjadi suatu indikator bahwa masyarakat merasa nyaman saat berada di Taman Kota Lumintang.

\section{Simpulan}

Hasil penelitian menyimpulkan bahwa mayoritas wilayah domisili masyarakat pengguna Taman Kota Lumintang sebesar $91 \%$ berada di wilayah Kota Denpasar, dan selebihnya berdomisili di Kabupaten Badung dan Gianyar, dengan pengguna Taman Kota Lumintang terbanyak berdomisili di wilayah Kecamatan Denpasar Utara. Adapun Radius Jangkauan wilayah pengguna rutin Taman Kota Lumintang adalah antara $0-4 \mathrm{~km}$ dari Taman Kota Lumintang. Jumlah frekuensi kunjungan masyarakat ke Taman Kota Lumintang terbanyak adalah satu sampai dua kali dalam seminggu. Aktivitas yang dilakukan oleh pengunjung berupa olahraga, rekreasi, dan pendidikan, namun yang paling sering dilakukan di Taman Kota Lumintang adalah berolahraga. Hal ini sesuai dengan tujuan dibangunnya Taman Kota Lumintang yaitu sebagai sarana aktivitas publik di wilayah perkotaan dalam bentuk RTH.

\section{Daftar Pustaka}

Badan Perencanaan Pembangunan Daerah Kota Denpasar. Tt. Ruang Terbuka Hijau. Available online at: http://bappeda.denpasarkota.go.id/ (diakses pada Oktober 2018).

Badan Pusat Statistik Kota Denpasar. 2018. Kota Denpasar Dalam Angka 2018.

Haryadi \& B. Setiawan. 2010. Arsitektur, Lingkungan dan Perilaku: Pengantar ke Teori, Metodologi, dan Aplikasll. Gadjah Mada University Press. Yogyakarta.

Gaol, L.W. 2010. Kajian Nilai Ekonomi Taman Kota Sebagai Ruang Terbuka Hijau (Studi Kasus di Taman Bunga Pematangsiantar Provinsi Sumatera Utara). http://repository.usu.ac.id/handle/123456789/22042?show=full.

Mulato, F. 2008. Ketersediaan Ruang Terbuka Publik Dengan Aktivitas Rekreasi Masyarakat Penghuni Perumnas Banyumanik. http://eprintsundip.ac.id/3916/1/fajar_mulato.pdf.

Peraturan Menteri Dalam Negeri Nomor 1 Tahun 2007. Tentang Penataan Ruang Terbuka Hijau Kawasan Perkotaan.

Peraturan Menteri Pekerjaan Umum Nomor 5 Tahun 2008. Tentang Pedoman Penyediaan dan Pemanfaatan Ruang Terbuka Hijau di Kawasan Perkotaan.

Wahyudi. 2009. Ketersediaan Alokasi Ruang Terbuka Hijau Kota Pada Ordo Kota I Kabupaten Kudus. Tesis. Program Magister IImu Lingkungan Universitas Diponogoro. http://eprints. undip.ac.id/17639/1/WAHYUDI.pdf. 